\title{
Jak zkoumat koalice v Radě EU? Analýza výzkumných př́stupů ke koaličnímu chování v Radě EU ${ }^{1}$
}

\author{
Petr Kaniok, Petra Kuchyňkováa
}

\begin{abstract}
Examining Coalitions in the Council of the European Union. Analysis of Research Approaches to Coalition Behaviour in the Council.

Both in the Czech and European contexts, the Council of the EU is a relatively frequent subject of interest in political science research. A substantial amount of work (both in the tradition of qualitative and quantitative research) focuses especially on the process of coalition building and the impact and functioning of the different levels of the Council. This theoretical discussion analyzes the possibilities which both the qualitative and quantitative approaches offer concerning research dealing with the coalition behavior of one concrete EU member state. In doing so, it takes into account various specifics which characterize the Council of the EU and which substantially influence the behavior of its member states. The paper concludes that the qualitative approach (while being to a substantial degree complementary to the quantitative tradition) offers better tools for an analysis focusing on the coalition behavior of one member state than its quantitative counterpart. One of the reasons lies in the nature of our research which deals with the process of promoting the interests of the Caech Republic in the EU Council, with a special emphasis on coalition building and searching for compromises.
\end{abstract}

Keywords: EU Council, Coalition Bargaining, Informal Condition, Consensus, Qualitative Approach

\section{1. Úvod}

Přestože v posledních letech došlo také $\mathrm{v}$ českém prostředí $\mathrm{k}$ nárůstu studií a výzkumu (Zbíral 2008a, Zbíral 2008b, Belko 2009, Plechanovová 2011, Parízek 2012), který se zabývá chováním států v Radě EU, dosud žádná pozornost nebyla systematicky věnována koaličnímu chování České republiky v této zásadní instituci EU. Domníváme se, že po téměř deseti letech členství ČR vEU a působení českých zástupců ve všech úrovních Rady existuje dostatek dat nejen kvantitativní, ale také kvalitativní povahy, a je tedy na čase tuto mezeru zaplnit a pokusit se odpovědět na zdánlivě banální základní otázku znějící: ,jakou pozici má ČR v Radě EU, jakým aktérem (hráčem) v procesech vyjednávání a tvorby koalic v rámci této mezivládní instituce je?“ Je logické, že taková analýza musí probíhat $\mathrm{v}$ několika fázích, z nichž první musí být reflexe dosavadního výzkumu koaličního chování států v EU a dále výběr a zdůvodnění metody či metod pro vlastní analýzu. Teprve poté může následovat sběr dat, jejich analýza a konečně interpretace výsledků a diskuze s dosud známými poznatky. Všechny tyto etapy lze jen stěží komplexně vyložit v rámci jednoho textu. Koneckonců, samotná otázka směrující na pozici ČR v Radě EU vyžaduje doplnění prostřednictvím skupiny dílčích otázek.

\footnotetext{
1 Tento článek vznikl v rámci projektu s názvem "Prosazování zájmů ČR v rozhodovacích orgánech EU. Hledání kompromisů, budování koalic $\mathrm{v}$ Evropské radě a Radě EU a spolupráce s ostatními institucemi EU” (TB010MZV038). Projekt byl řešen s finanční podporou Technologické agentury České republiky.

${ }^{2}$ Katedra mezinárodních vztahů a evropských studií, Fakulta sociálních studií, Masarykova univerzita, Joštova 10, 60200 Brno. Kontakty: kaniok@fss.muni.cz,P.Kuchynkova@seznam.cz
} 
Předložený článek má za cíl pokrýt prvně dvě jmenované fáze, a to s důrazem na zdůvodnění toho, co nám různé výzkumné tradice mohou o Radě EU a koaličním chování v něm sdělit. Předkládaná konzultace je tedy úvodem do konkrétního výzkumu koaličního chování ČR, který má za cíl ověřit, jak se projevují v př́padě partikulárního státu, jenž je prozatím ještě stále relativně mladým členem EU, obecnější předpoklady týkající se koaličních vzorců v jednotlivých tematických oblastech a na jednotlivých úrovních Rady. Výzkum se opírá na jedné straně o teoretická východiska racionalismu a teorie racionální volby, která operují s předpokladem vytváření ad hoc koalic na základě konkrétních zájmových preferencí. $\mathrm{Na}$ druhé straně potom bere v úvahu premisy konstruktivismu (který do výzkumu institucí zasáhl také významným vlivem na nový institucionalismus) vyzdvihující význam určitých institucionalizovaných, stálých koalic založených na geografické či kulturně-politické blízkosti, tradici skupinové politické spolupráce apod. (v př́padě členských zemí vstoupivších do EU v roce 2004 se typicky jedná o spolupráci na bázi Visegrádské skupiny). Ve vlastním výzkumu se však nejedná jen o ověřování předpokladu, jakým koalicím a za jakých podmínek dává prŕslušný stát přednost, ale také o otázky, jaké motivy determinují v konkrétních př́padech zástupce ČR jako členského státu k výběru př́slušných koaličních partnerů, prrípadně ke změnám v koaličním chování, a jaké další faktory (endogenní i exogenní povahy) vstupují do procesu vyjednávání apod.

Za tímto účelem se předkládaný text nejprve zamýšlí nad výhodami a nevýhodami kvantitativně a kvalitativně orientovaného výzkumu koalic v Radě EU a koaličního chování členských států či státu. Jakkoliv se jedná o dvě odlišná témata, jejich výzkum spolu tematicky úzce souvisí: Žádný koaliční aktér se nepohybuje v institucionálním vzduchoprázdnu, zároveň je ale každý natolik specifický, že jej nelze redukovat na pouhého řadového nositele určité hlasovací síly. Na základě reflexe obou tradic se s přihlédnutím ke specifikům Rady EU snažíme představit, na jaké otázky nám může kvantitativní či kvalitativní výzkum stran koaliční tematiky odpovědět. Jinými slovy, v tomto textu bychom rádi zjistili, jaký druh výzkumu je pro analýzu koaličního chování jedné členské země vhodný.

Struktura našeho textu je následující. V první kapitole stručně představujeme Radu EU, její základní funkce a charakteristiky, s důrazem na specifika její činnosti v politickém systému EU. Domníváme se totiž, že ačkoli je předmětem našeho výzkumu koaliční chování členského státu a jeho chování jakožto aktéra v procesu vyjednávání, je tato dílčí problematika neoddělitelná od problematiky výzkumu Rady jakožto instituce, která funguje specifickým zpo̊sobem a jednání aktéra v ní se řídí specifickými pravidly. Chceme-li odpovědět na otázku, jaké jsou výhody a nevýhody kvantitativně a kvalitativně orientovaného výzkumu koaličního chování členských států v Radě a co z toho vyplývá pro výzkum týkající se konkrétního členského státu, je nutné ptát se, zda specifická povaha vyplývající ze struktury, norem, procesů typických pro Radu i samotných aktérů, kteři v Radě zastupují členské státy, nemá př́ślušné implikace i pro výběr vhodné metodologie. Druhý úsek je zaměřen na analýzu stavu kvantitativního výzkumu, který vysvětluje jednání členských států v Radě EU, zatímco ve třetí části konzultace představujeme kvalitativní tradici a její explanační potenciál. V závěrečné pasáži pak shrnujeme důsledky, jež z našeho textu vyplývají pro výzkum koaličního jednání konkrétní členské země, a nastiňujeme směr našeho dalšího výzkumu. 


\section{Rada EU a její specifika}

Rada EU patří $\mathrm{k}$ nejdůležitějším institucím $\mathrm{EU}$, což se odráží zejména $\mathrm{v}$ jejím podílu na schvalování sekundární legislativy a rozpočtu EU. Neméně důležitá je ale její funkce legitimní platformy pro artikulaci a prosazování zájmů a představ členských zemí. V nejobecnějǔś rovině jsou v Radě členské státy zastoupeny dle své populační síly, na jejímž základě jsou jim prídělovány vážené hlasy (Taagepera, Hosli 2006)ํ․․ Jejich pomocí, spolu s počtem zemí (a na vyžádání přepočtem vážených hlasů a zemí na obyvatelstvo EU), Rada rozhoduje a plní své funkce. Při vykonávání své činnosti ovšem Rada nepředstavuje homogenní a snadno uchopitelnou entitu. Naopak se jedná o instituci, která je svým vnitřním nastavením natolik specifická, že ji lze obtížně srovnávat s jinými ministerskými platformami mezinárodních organizací, ${ }^{4}$ a že tak představuje instituci svého druhu. Specifika Rady, na jejichž nejdůležitější prvky chceme v této sekci poukázat, přitom ovlivňují její výzkum, respektive podmiňují volbu výzkumné strategie při hledání odpovědí na konkrétní problémy související s koaličním chováním dané členské země či členských zemí.

Prvním specifikem Rady je, že zájmy členských zemí jsou vyjadřovány na třech různě koncipovaných úrovních (Häge 2007: 302-304). První tvoří pracovní skupiny, jejichž úkolem je projednávat především věcnou stránku navrhovaných předloh, druhou je COREPER a př́pravné výbory, jež při vyjednávání zohledňují politické aspekty preferencí členských států, a konečně třetí skupinu tvoři resortní ministři, dojednávající zásadní politické otázky a formálně schvalující legislativu, u které byla faktická shoda dosažena na nižších úrovních. V souvislosti s distribucí vlivu jednotlivých úrovní se dlouhodobě favorizoval vliv pracovních skupin a COREPER na úkor ministrů (Hayes-Renshaw - Wallace 2006, Beyers 2005), v poslední době ale empirické studie doložily, že ministerská úroveň se svým vlivem technokratickým a polopolitickým fázím jednání vyrovná (Häge 2008). Během vyjednávacího procesu nicméně prosazování zájmů zohledňuje celou řadu perspektiv, priččmž neplatí, že by role jednotlivých složek byla striktně oddělena. Např́klad studie Foilleuxe a kol. uvádí, že pracovní skupiny se v celé řadě př́padů věnují nejen technickým aspektům legislativy, ale také politickým souvislostem a mnohdy celou legislativu prakticky dojednají (Foilleux - de Maillard - Smith 2005).

Dalším podstatným specifikem je význam kultury kompromisu pro rozhodování v Radě EU. Ačkoliv je podle primárního práva rozhodovacím nástrojem Rady hlasování, a to zejména kvalifikovanou většinou (QMV), fakticky k němu dochází zř́idka. Byt' jsou hladiny QMV či s ní související blokační menšiny nastaveny na velmi vysoké hodnoty, v Radě se zpravidla vyjednává do dosažení maximálního možného konsensu, který hodnotu QMV přesahuje (Heisenberg 2005). Neformální a nepsaná pravidla mají své dalši rozměry: omezené působení má např́iklad formálně závazný Jednací rád Rady - základní norma, která upravuje chování zástupců členských států při jednání Rady a jejích složek. Ačkoliv Jednací řád Rady oficiálně zakazuje např́klad použití tzv.

\footnotetext{
${ }^{3}$ V Radě EU neexistují jasná a explicitní kritéria, podle nichž jsou státům vážené hlasy přidělovány. Citovaná studie Taagepery a Hosliové ale ukázala, že právě populace sehrává rozhodující roli.

${ }^{4}$ Př́kladem může být naprŕíklad Severská rada ministrů, která rovněž funguje na sektorovém ministerském principu.
} 
kulatého stolu, podle účastníků jednání neexistuje síla, která by delegátům zamezila přednést stanovisko vlády, kterou zastupují.

S významem hlasování a vyjednávání jako nástroje rozhodování souvisí také problematika tzv. transparentnosti. Od roku 2002, kdy byl na základě Závěrů Evropské rady ze Sevilly novelizován jednací řád Rady, jsou veškerá jednání, kdy Rada EU rozhoduje o legislativní předloze, veřejná a mohou být např́ílad sledovaná prostřednictvím webstreamu. Tento krok, který je často považován za krok k demokratizaci Rady a její větší kontrolovatelnosti, nicméně podle aktérů vedl $\mathrm{k}$ tomu, že se ještě více jednání přsesunula z jednacích sálů do kuloárů a přenášená zasedání představují $\mathrm{v}$ lepším případě zlomek skutečných procesů, v horším pouze předstírané divadlo. ${ }^{5}$

Čtvrtým specifikem Rady je povaha aktérů, kteří v jejích různých tělesech zasedají. Zástupci států se liší nejen dle své politické či odborné kompetence, ale také povahou svého primárního působiště. $\mathrm{V}$ části pracovních skupin či př́pravných výborů zasedají diplomaté působící na stálých zastoupeních členských států, kteři se permanentně pohybují v Bruselu. Řada skupin je naopak obsazována experty, kteří na jednání dojíždí z jednotlivých států, což pak plně platí o ministerské úrovni. Různá míra permanentnosti pobytu v Bruselu logicky vede k odlišné hloubce socializace u různých aktérů a ke vzniku různých druhů loajality - př́íladem může být Výbor stálých zástupců (COREPER), jehož členové jsou zpravidla loajální nejen své vládě, ale cítí se být zodpovědní také nepsanému zákonu velícímu dospět k dohodě (Bostock 2002: 217-218).

Pátým zvláštním znakem Rady je způsob jejího řízení. Rada je od vzniku Evropského společenství uhlí a oceli vedena rotačním předsednictvím, ve kterém se všechny členské státy $\mathrm{v}$ pravidelném šestiměsičním intervalu stř́dají. Předsednický stát má celou řadu úkolů, z pohledu koaličního chování je důležité, že k nim patří také role architekta konsensu v Radě EU. Kromě povinností má předsednická země nespornou výhodu oproti ostatním zemím, spočívající např́klad $\mathrm{v}$ privilegovaném př́stupu $\mathrm{k}$ informacím, což může předsednický stát oproti ostatním v koaličním vyjednávání zvýhodnit (Kaniok 2008). Na druhou stranu se ovšem předsednictví musí chovat nestranně, což pro daný stát znamená svým způsobem schizofrenní situaci. Jen obtížně si lze představit zemi, která krátkodobě „zapomene“ na své dlouhodobé zájmy, tlak ostatních zemí na dodržování normy nestrannosti je ovšem obrovský.

Šestým specifikem jednání Rady je, že charakter jednání neurčují pouze interní normy (at' už formální či neformálnî) instituce, ale také vnější pravidla. Rada se nepohybuje v institucionálním vzduchoprázdnu, ale většinu své činnosti pracuje v kontaktu s dalšími institucemi EU, zejména s Evropským parlamentem (EP) a Evropskou komisí (EK). Odlišné rozhodovací procedury, do nichž je Rada zapojena např́klad při schvalování legislativy, mají prŕmý dopad na jednání aktérů Rady - přičemž tyto podmínky jsou zvnějšku dané a mnohdy nepředvídatelné, protože jak EP, tak EK jsou instituce odlišné povahy než Rada, jelikož v politickém systému EU hájí zájmy svébytného typu.

\footnotetext{
5 Tento poznatek uvedli v rozhovorech s autory článku např́klad diplomaté - pracovníci Stálého zastoupení České republiky při Evropské unii.
} 
Zatímco prvních šest charakteristických rysů platí o Radě obecně (a de facto ovlivňovaly její činnost od vzniku Rady), sedmá vlastnost bude relevantní teprve od listopadu 2014. Ačkoliv naše konzultace rezignuje na jakékoliv prognostické ambice, uvádíme ji proto, že většinu výše zmíněných specifik tato vlastnost nejspíše podstatně ovlivní. Díky ustanovení článku 16 Smlouvy o Evropské unii ve znění Lisabonské smlouvy se totiž od listopadu 2014 změní konstrukce QMV. Zásadní novinkou je vypuštění vážených hlasů a zjednodušení složení QMV pouze na počet hlasujících zemí a jejich populační sílu. Do listopadu 2017 mají mít státy k dispozici jak nový způsob hlasování, tak na vyžádání dosud platnou konstrukci zohledňuící vážené hlasy. Po listopadu 2017 by již měla fungovat pouze nová úprava. Zjevným důsledkem této změny je posílení pozice lidnatějších států na úkor malých populačně méně silných zemí. ${ }^{6}$

\section{Přehled kvantitativního výzkumu}

V předchozích odstavcích mají nastíněná specifika Rady EU důležité dopady pro výzkum chování aktérů vyjednávacího procesu. V obecné rovině lze konstatovat, že výzkum chování států v Radě EU sleduje svým rozdělením na kvalitativně a kvantitativně orientovanou produkci základní teoretickou debatu mezi racionalisty a konstruktivisty (Pollack 2002), která modernímu zkoumání evropské integrace určuje základní vymezení.

Tvrzení, že kvantitativně zaměřený výzkum Rady EU v dnešní produkci dominuje, lze doložit především širrí témat, která pokrývá, pestrým spektrem použitých př́istupů a koneckonců pohledem na objem studií a knih, které jej využívají. Jejich společným vodítkem je konstrukce zájmu a chování státu jako neměnné hodnoty, mající racionální a exogenní povahu, která je nezávislá např́ílad na sociální interakci v Radě EU. Velmi obecně lze takto orientovaný výzkum rozdělit na teoretické studie, pracující např́ílad s indexy hlasovací/volební síly, a empiricky zaměřené práce, které vycházejí z konkrétních datasetů. Z našeho pohledu jsou nicméně zajímavé empiricky orientované studie, protože se zaměrují na výzkum skutečného chování státu/států. Podrobněji komentovat ryze teoretický výzkum nemá z hlediska našeho textu valného smyslu, ${ }^{7}$ protože oproti empirickým studiím nepracuje s reálnými daty a reálným chováním aktérů rozhodování a vyjednávání v Radě EU. Nijak tím samozřejmě nesnižujeme jeho význam pro utváření obecných hypotéz, které může empirický výzkum prověřit.

Empirický směr výzkumu se opírá o skutečná hlasování a reálně vyjádřené pozice. V prvním př́padě jsou zpracovávána zaznamenaná hlasování Rady EU (např́klad Mattila 2005, Aspinwall 2006, Hagemann 2008), ve druhém jsou analyzovány změny v pozicích států od jejich původní pozice ke konečnému výsledku (např́iklad Thomson 2006). Pozice států jsou zpravidla

\footnotetext{
6 Zajímavé výsledky v této souvislosti přináší analýza Barra a Passarelliho (Barr, Passarelli 2009), kteří pomocí matematické analýzy dospěli k závěru, že dvojí většina, kterou Lisabonská smlouva zavádí, bude favorizovat velké a politicky umírněné země.

${ }_{7}$ Teoreticky zacílený výzkum není jednolitý a pokrývá pestrou škálu témat. První z nich představují teoretické práce, které se zabývají výpočtem hlasovací síly jednotlivých zemí a s ní souvisejícím koaličním potenciálem, případně důsledky pro uplatnění hlasování QMV (např́klad Hosli 1999, Hosli - Machover 2004). Výstupem těchto textů, pracujících s indexy hlasovací síly (Zbíral 2008a), je především modelování teoretických koalic a hlasovacích bloků či modalit konstrukce blokační menšiny. Další skupinou teoreticky koncipovaných textů jsou pak např́klad statě, jež se zaměřují na změny, které pro koaliční potenciál členské země má změna distribuce vážených hlasů (Plechanovová 2004, Plechanovová 2006).
} 
definovány na základě expertních posouzení aktérů jednání či analýzou speciálních bruselských periodik, které pokrývají vývoj sekundární legislativy, případně jsou koaliční vzorce vytvářeny na základě dat poskytnutých zástupci členských států v pracovních skupinách Rady EU (Naurin 2007). Výzkum skutečných hlasování či pozic dospěl stran hledání odpovědi na otázku, zda existují v Radě EU identifikovatelné koalice, k pestré směsi odpovědí. První skupina studií (např́klad Mattila - Lane 2001, Thomson - Boerefijn - Stokman 2004, Naurin 2007) poukazuje na př́tomnost konfliktní linie mezi severem a jihem, kdy např́klad Naurin (Naurin 2007) doložil, že na významu severo-jižní konfliktní linie nic nezměnilo ani masivní východní rozšíření. ${ }^{8}$ Naopak výzkumy Mattily (Mattila 2005) či Hagemannové a Høylanda (Hagemann, Høyland 2008) identifikovaly jako jednu z hlavních dimenzí pro koaliční chování pravicovou či levicovou orientaci vlád členských států, což alespoň do období před rozšířením EU potvrdila také studie Hagemannové (Hagemann 2008). Další studie (Aspinwall 2006, Veen 2011) pak poukázaly na relevanci podpory další evropské integrace, dělící státy na pro a protiintegrační. Část studií pak vyvrací tezi o tom, že koaliční vzorce lze nalézt např́č Radou EU (a jejími všemi formacemi), a místo toho dokládá existenci koalic, které se budují dle předmětu projednávané předlohy (Hayes et all 2006).

Specifickou podskupinou kvantitativně orientovaných textů jsou studie, jež analyzují pozici a vliv předsednictví. Jak jsme již uvedli, předsednictví představuje specifického koaličního aktéra, lišícího se od ostatních aktérů hlasování. Většina studií bere $\mathrm{v}$ úvahu především schopnost předsednictví prosadit své zájmy a učiněné závěry jsou rozporuplné. Zatímco jedna skupina předsednictví určitý vliv přiznává (Warntjen 2007, Schalk - Torenvlied - Wessie - Stokman 2007), jiní výzkumníci jej zpochybňují (Alexandrova - Timmermans 2013).

Obecně velkým prrínosem kvantitativní tradice je její schopnost generovat obecnější závěry, které se vztahují k celé populaci Rady, a ne pouze k její výseči. Statisticky zaměřené texty umožňují klást (a zodpovídat) otázky, ke kterým vybízí přítomnost hlasování jako rozhodovacího nástroje a konstrukce QMV. Existence koaličních vzorců, odvozených nejčastěji od geografické př́buznosti zemí, jsou typickým př́kladem takovéto otázky. Stejně tak logické jsou teoretické úvahy modelující různé situace závisející na přidělení toho či onoho počtu vážených hlasů členským zemím. Vážené hlasy se přepočítávají po každém rozšiřování EU, přičemž vždy přepočet uměle zvýhodňoval menší členské státy na úkor větších zemí. Modelování různých hypotetických situací je tedy nejenže legitimní, ale také politicky relevantní téma. ${ }^{9}$

Jakkoliv jsou ovšem výsledky kvantitativních studií úctyhodné, již jejich samotná rozpornost a pestrost vzbuzuje otazník, nakolik jsou zjištěné závěry validní a vypovídají nikoliv o daném datasetu, ale o Radě jako celku. Prvním obecným problémem je, že jednotlivé studie pracují s odlišnými datasety, různě zdůvodňují výběr případů a nezřídka tak docházejí, byt' používají podobné metody, $\mathrm{k}$ diametrálně odlišným závěrům. Ještě významnější výtkou je, že výzkum skutečných hlasování představuje výzkum pouze mizivého procenta rozhodnutí Rady. Jeho

\footnotetext{
8 Studie Mattily (2009) nicméně poukazuje na to, že jiho-severní dimenzi doplnila po východním rozšî̌rení ještě zřetelná dimenze nových členských států a rekonfigurovala tak prostor Rady na jiho-severo-východní.

9 Stačí vzpomenout na diskuze, které se např́iklad na Konventu o budoucnosti Evropské unie objevovaly v souvislosti s přidělením vážených hlasů.
} 
výpovědní hodnota je proto omezená. Vlivem řady faktorů, $k$ nimž patři zejména již zmíněná specifika činnosti Rady, není hlasování (jakkoliv je formálně hlavním rozhodovacím nástrojem) zdaleka tak důležité jako vyjednávání. Členské státy jsou - at’ už tlakem předsednického vedení, které se snaží minimalizovat opozici a tím pádem počet nespokojených zemí, či obavou z reciprocity - vedeny $\mathrm{k}$ vyjednávání do stavu, kdy s výsledným tvarem kompromisu souhlasí bud’ všechny země, či téměř všechny. O drtivé většině položek, které se dostanou na stůl ministrům, se vůbec nehlasuje, ale jsou předjednané na nižších úrovních. Celkový podíl ministrů na rozhodování pak představuje přibližně $20 \%$ z celkové agendy Rady, což vede k myšlence, že koaliční vzorce vzniklé např́iklad na úrovni COREPER jsou stran výsledku závažnější. Hlasování ministrů, dojde-li $\mathrm{k}$ němu, navíc nemusí být vůbec motivováno pomyslným bojem za národní zájem, ale může být podmíněno vnitropolitickými důvody. ${ }^{10}$ Problém je ukryt také v samotných datech, jež vypovídají pouze o poražených státech. ${ }^{11}$

Výhrady lze vznést také ke kvantifikaci pozic členských států. Jejich samotná konstrukce je do značné míry zpochybnitelná tím, že často bývá založena na ex post úsudku aktérů, jejichž evaluace může být subjektivně zabarvená. Jak navíc uvádí Naurin, pozice není totéž, co koalice, a z prostého faktu, že např́klad Řecko, Irsko a Portugalsko drží k dané předloze stejnou pozici, nelze usuzovat, že tyto tři státy budou také spolupracovat a že utvoří přirozené koaliční spojenectví (Naurin 2007: 5).

Další rovinou je, že plošné kvantitativní výzkumy nejsou schopny zohlednit posuny v koalicích a pozicích, jež mohou nastávat na různých úrovních Rady, počínaje pracovními skupinami a ministry konče. V neposlední řadě neberou do úvahy vlivy, které preference aktérů mění, jako je např́klad jejich socializace či naopak krátká doba působení. Jejich produktem tak zpravidla je statické zachycení malého výseku pestrého obrazu, jímž chování států v Radě EU je. Tato slabina je patrná např́klad u jinak zajímavých dat, jež stojí za výzkumy Naurina (Naurin 2007, Naurin - Lindahl 2008). Zjištění koaličních vzorců u pracovních skupin totiž neznamená, že stejné koaliční vzorce se přenášejí také do vyšších úrovní Rady EU, zejména pak mezi ministry a COREPER.

Dosavadnímu kvantitativnímu výzkumu rozhodně nelze upřít př́nos, který má z hlediska testování hypotéz týkajících se koaličních vzorců, opírajících se o různá teoretická východiska (at' již vycházející z racionalistických, konstruktivistických či jiných pozic). Detailní analýza jednoho př́padu koaličního chování členského státu s využitím kvalitativního výzkumu na druhé straně umožňuje získat expertní znalosti týkající se praktického působení členského státu jako aktéra vyjednávacích procesů za využití př́islušných hypotéz (teoretických předpokladů) (Kořan 2008: 29). V rámci takového výzkumu si můžeme klást následující otázky: Platí pro chování př́islušného

\footnotetext{
${ }^{10}$ Jedná se o tzv. falešné B-body, které jsou fakticky dojednané na úrovni COREPER, ale ministři o nich - často z mediálních či vnitropolitických důvodů, kdy ministr potřebuje doložit, že za zájem dané země skutečně bojoval formálně jednají a hlasují (Fiala - Pitrová 2009: 240).

11 Plechanovová (Plechanovová 2011a) byla pro svůj výzkum vlivu východního rozšíření schopna nalézt alespoň jeden disentující stát pouze ve 207 případech z celkových 3399 potenciálně použitelných předloh. Rovněž následný text Plechanovové (Plechanovová 2011b) testující vypovídací schopnosti různých statistických metod pracoval pouze se 414 položkami z celkového počtu 6733 zaznamenaných předloh. Z daných 414 položek, kde se některý aktér bud’ zdržel hlasování, či hlasoval proti, pak bylo cca $40 \%$ předloh, kde opozici tvořil pouze jeden stát.
} 
státu v Radě EU, že jeho geografická pozice je důležitou determinantou jeho koaličního potenciálu? Funguje jako motiv pro bližší koalici na evropské integraci nezávislá regionální kooperace typu visegrádské spolupráce? Sehrává svou roli při budování koalic politická profilace vlád? Je možné klást otázky, co vede členský stát a jeho zástupce $\mathrm{k}$ výběru př́íslušných koaličních partnerů a k setrvávání $\mathrm{v}$ prŕśslušných koalicích, či naopak k proměnám v koaličním chování, a to i $\mathrm{v}$ průběhu vyjednávacího procesu $\mathrm{v}$ konkrétních případech. Výsledkem takového výzkumu může být i formulace nových hypotéz, případně doplnění či zpřesnění těch existujících, což prínáší další možnosti také pro výzkum kvantitativní.

\section{Kvalitativní výzkum}

Kvalitativní výzkum v politické vědě klade otázky vyžadující detailní odpovědi, umožňuje zachytit jedinečné skutečnosti (Drulák 2008:14), např. osobní reflexi událostí ze strany př́mých účastníků (reprezentantů př́slušného členského státu na různých úrovních Rady) apod. Vromenová zmiňuje, že metody kvalitativního výzkumu jsou často využívány badateli, kteří epistemologicky vycházejí z jiných nežli pozitivistických stanovisek, badateli využívajícími spíše interpretativní př́stup a snahu o porozumění zkoumanému výseku reality. Takové vymezení však nelze chápat striktně (Vromen 2010: 249 či Drulák 2008: 15), metody typické pro kvalitativní výzkum mohou být využity jak pro výzkum usilující o vysvětlení a nalezení kauzálních vztahů, tak pro výzkum interpretativní.

Stejně tak nelze z hlediska vztahu mezi ontologií a epistemologií říci, že určitá teoretická východiska jednoznačně implikují využití kvalitativní metodologie v př́slušném výzkumu, ačkoli na toto téma jsou vedeny debaty (např. Drulák 2008: 23-24). Kvalitativní výzkumné techniky jsou např. nezřídka využívány při výzkumech opírajících se teoreticky o premisy nového institucionalismu a konstruktivismu (Maillard - Smith 2011: 11), nahlížející na sociální realitu jakožto na konstrukt, na kterém se jednotliví aktéři (v našem případě aktéři vyjednávání a procesu tvorby koalic na různých úrovních Rady) aktivně podílejí. Vyjednávání v Radě je takto pojímáno jakožto reprodukující se proces (Risse 2009: 145), který vytváří specifická pravidla, jež nemusí vždy odpovídat formálním pravidlům zachyceným např. v jednacích řádech. Vytváří se tak svébytná „kultura“ instituce, která zpětně ovlivňuje i účastnící se aktéry, kteří (na rozdíl od racionalistického pojetî) nejsou na prostředí nezávislí. Identity i zájmy aktérů jsou normami, které nemusí být jen formálního charakteru, ovlivňovány. Účastníci těchto procesů tedy nejsou jen pasivními př́jemci pravidel, ale sami je spoluutvářejí (Chryssochoou 2009: 112). Na druhé straně je ale pravdou, že kvalitativní metody pro sběr dat jsou využívány i při výzkumech teoreticky vycházejících z realistických premis a naopak socializační efekt nap̌r. opakovaných jednání institucí EU, včetně Rady, byl v minulosti často zkoumán také s využitím kvantitativních analýz (Checkel 2005: 807).

V následující části budou rozebrány př́klady témat, která Rada EU nabízí kvalitativnímu výzkumu, a to právě s ohledem na své specifické charakteristiky jakožto instituce EU, jež byly popsány v části II. Prvním tématem, které Rada této výzkumné tradici nabízí svou specifičností, 
je její víceúrovňová struktura. ${ }^{12}$ Jak zdůrazňuje Heisenbergová, ${ }^{13}$ kvalitativní výzkum dovede postihnout význam těchto nižších struktur typu COREPER, na rozdíl např́lklad od těch kvantitativních výzkumů, které jsou zaměřeny pouze na analýzu dat, jež jsou výsledkem hlasování, a posléze umožňuje např. konstruovat hypotézy o tom, jak a za jakých okolností tyto struktury mohou využívat svoji roli v rozhodovacím procesu apod. (Heisenberg 2008: 272). $\mathrm{V}$ tomto kontextu je dobré připomenout skutečnost, že k velké části rozhodnutí, která jsou následně pouze formálně schvalována na ministerské úrovni, zástupci členských států procesem vyjednávání dospívají právě na prŕpravné úrovni. Podle některých zdrojů je to 70 až $90 \%$ rozhodnutí, která již na ministerské úrovni nejsou ani diskutována (Olsen 2010: 2). Kvalitativní tradice je proto použitelná např́klad při detailním zkoumání procesů odehrávajících se na těchto nižších úrovních (pracovní skupiny, přípravné výbory, COREPER) a při výzkumu jejich zapojení do rozhodovacího procesu. ${ }^{14}$ Prostřednictvím kvalitativního výzkumu vyjednávání a utváření

\footnotetext{
12 Ze starších studií, které se detailně věnují roli jednotlivých úrovní Rady v každodennímu procesu rozhodování , lze zmínit např. výzkum úlohy COREPERu demonstrované na komparaci 2 př́padů projednávání legislativních aktů v Radě (Lewis, 2003). Z novějších kvalitativních výzkumů zaměřených též na COREPER, jeho fungování a efektivitu $\mathrm{v}$ rámci struktury Rady po východním rozšíření EU lze jmenovat text Jakoba Lemppa z roku 2007 zaměřený na výzkum existence cleavages mezi staršími a novějšími státy EU-25 na úrovni COREPER, včetně zohledňování takových faktorů, jako je „služební stáří prúslušných úředníků apod. Výzkum je založen výhradně na polostrukturovaných elite-interviews s členy stálého zastoupení, př́slušných sektorových ministerstev a Generálního sekretariátu (GS) Rady (Lempp 2007).

${ }^{13}$ Text Dorothey Heisenbergové How Should We Best Study the Council of Ministers? vyšel jako kapitola v knize editorů Daniela Naurina a Helen Wallaceové Unveiling the Council of the European Union. Games Governments Play in Brussels. Knihu lze považovat za cenný příspěvek právě $\mathrm{k}$ debatě týkající se různých př́istupů k výzkumu Rady EU, který volá po systematičtějším zpracování rostoucího množství kvantitativních a kvalitativních dat, jež jsou díky již proběhnuvším výzkumům v současnosti $\mathrm{k}$ dispozici. V závěrečné části nazvané Metodologická debata upozorňuje text D. Heisenbergové jak na specifickou povahu Rady jakožto instituce, tak i na skutečnost, že kvantitativní výzkum neumožňuje získávat relevantní data týkající se faktorů významně ovlivňujících rozhodovací proces $\mathrm{v}$ této instituci (např. postojů a individuálních preferencí jednotlivých reprezentantů členských států na různých úrovních Rady, neformálních pravidel jednání apod.). Z těchto důvodů dle Heisenbergové kvalitativní empirický výzkum v případě Rady EU slouží nejen lépe pro formulaci relevantních výzkumných otázek, ale dokonce i pro jejich zodpovězení. Autorka proto $v$ této souvislosti varuje před tím, aby se výzkum EU a jejích institucí ubíral podobným směrem jako americká politická věda, jejímuž výzkumu v duchu behaviorální tradice kvantitativní metodologie dominuje (Naurin - Wallace 2008: 15; Heisenberg 2008: 261-267). Heisenbergové oponuje ve svém textu Gerald Schneider, podle kterého Heisenbergová dostatečně nereflektuje skutečný stav výzkumu v př́slušné oblasti, který právě díky obratu k principům normální vědy ( $\mathrm{v}$ Kuhnově smyslu) v posledních letech významně posílil ve schopnosti explicitního testování hypotéz, striktním důrazu na „vědeckost“ politické vědy i ve schopnosti odpovídat právě na ty otázky, na něž podle Heisenbergové výzkum držící se kvantitativní tradice odpovědi nedává (Naurin - Wallace 2008: 15-16; Schneider 2008: 277-289). Ve výsledku lze ovšem paradoxně říci, že poměrně konfrontační tón obou textů spíše potvrzoval, než vyvracel dojem nedostatku skutečné debaty, ochoty ke komunikaci mezi oběma výzkumnými př́stupy i badateli, kteří s nimi pracují, stejně jako snahy efektivně využívat přínosů obou přístupů (což doznávali i autoři zmíněné knihy).

Novějším pokusem o systematizaci výzkumu a výzkumných poznatků v oblasti rozhodovacích procesů na úrovni EU (nejen v rámci Rady) může být např. projekt Decision-Making in the European Union Before and After Lisbon (DEUBAL) financovaný Evropskou komisí. který deklaruje snahu využívat pro obohacení výzkumu rozhodovacích procesů v EU v kontextu změn, které přinesla Lisabonská smlouva, mimo jiné jak kvantitativních, tak i kvalitativních empirických studií (DEUBAL).

14 Př́kladem kvalitativního výzkumu zaměřeného na pracovní skupiny v Radě a jejich aktivní participaci na rozhodovacím procesu může být výzkum de Maillarda a Smitha z roku 2003, který vycházel z teoretických pozic nového institucionalismu, konkrétně z těch předpokladů, které vyzdvihují úlohu autonomního jednání zkoumaných institucí. Výzkum se prostřednictvím případových studií a za využití techniky kvalitativních rozhovorů s úředníky členských zemí, ale také s relevantními úředníky EK a zástupci výborů EP, zabýval mimo jiné odlišnými způsoby dosahování kompromisu v pracovních skupinách v závislosti na tom, zda jejich vnitřnímu složení dominují úředníci ukotvení v rámci bruselského stálého zastoupení, i v závislosti na dalších sociologických faktorech týkajících se vnitřní kompozice prŕslušné pracovní skupiny. Zabýval se také odlišnými taktikami zástupců v pracovních skupinách
} 
koalic na těchto nižších úrovních je tak možné zkoumat, jak probíhá prosazování zájmů členských států, dosahování konsensu, jaký význam mají neformální pravidla procesu vyjednávání, vztahy mezi jednotlivými úrovněmi Rady a stadii vyjednávacího procesu apod.

Nutnost posouvat legislativní předlohy různými úrovněmi Rady akcentuje význam přesvědčování, argumentace či procesu sociálního učení (Risse 2009: 149-150). To má značný význam právě z hlediska otázky hledání konsensu. Kultura konsensu a snaha o dosahování kompromisu, řešení přijatelného pokud možno pro všechny zúčastněné, je přitom symptomatická pro proces vyjednávání v Radě i za situace, kdy prostrednictvím revizí primárního práva došlo k masivnímu rozšíření hlasování kvalifikovanou většinou. Kultura konsensu a kompromisu je tedy dalším specifikem, které předurčuje procesy probíhající na různých úrovních Rady ke kvalitativnímu výzkumu. Ke kultuře konsensu totiž náleží důležitá role různých komunikačních technik a na druhé straně empatie vưči odlišným zájmům (Zbíral 2008b: 103), což př́spívá $\mathrm{k}$ modifikaci původně zastávaných pozic a $\mathrm{k}$ hledání alternativ, a to často nezávisle na strategických úvahách (Risse 2009: 149). Jak zdůrazňuje Aus, kvalitativní výzkum využívající z metodologického hlediska často prŕpadové studie je schopen např́lklad přinést odpověd’ na otázku, do jaké míry při této modifikaci a přizpůsobování pozic členských států hrají roli sdílené normy či hodnoty, na úkor prosazování vlastní zájmové preference v partikulární oblasti (Aus 2008: 103). Tato schopnost kvalitativního výzkumu může hrát důležitou roli také při zkoumání tvorby koalic za účelem vysvětlení některých změn, $\mathrm{k}$ nimž v tomto procesu dochází.

Důležitou charakteristikou Rady je též specifická povaha aktérů jednání na jejích jednotlivých úrovních. Zástupci států zasedají opakovaně, což posiluje právě prvek sociálního učení, včetně utváření neformálních kontaktů a pravidel. Specifická je z tohoto pohledu jednak pozice COREPER, jednak pozice nižších úředníků stálých zastoupení členských států účastnících se jednání pracovních skupin. Ukotvení těchto úředníků v rámci stálých zastoupení umocňuje prvek dlouhodobého charakteru vzájemných interakcí, který spolu s určitou „izolovaností“ (na rozdíl od zástupců na úrovni pracovních skupin či ministerské úrovni, kteři na jednání přijíždějí z členských států) podporuje adaptační působení. ${ }^{15}$

Jak již bylo zmíněno, výhodou kvalitativního výzkumu ${ }^{16}$ je to, že umožňuje soustředit se na vyjednávání a vytváření koalic jakožto na proces. Ke koalicím proto není prústupováno jako ke statickým formacím aktérů, kteři „,koordinují své chování za účelem dosažení cílů, na nichž se

\footnotetext{
(např. zástupců menších členských států na jedné straně a států větší velikosti na straně druhé) ve vztahu k vyšší úrovni Rady reprezentované COREPERem apod. (de Maillard and Smith 2003).

15 Z kvalitativních výzkumů zaměřených na pracovní skupiny lze upozornit i na text Any E. Juncos a Karoliny Pomorské, které se zabývaly konkrétní oblastí společné zahraniční a bezpečnostní politiky a vlivem východního rozšírení EU na roli pracovních skupin v rozhodovacím procesu v této oblasti. Výzkum se věnoval také procesům socializace a adaptace nových členů na neformální procesy kooperace a tvorby koalic v této oblasti, v níž rozhodující úlohu hraje dosahování rozhodnutí prostřednictvím konsensu. Stěžejní výzkumnou technikou byly elite interviews vedené s reprezentanty členských států v pracovních skupinách Rady a pracovníky úřednického aparátu EK a GS Rady (Juncos - Pomorska, 2007).

${ }^{16}$ Kvalitativní výzkum a jeho techniky jsou též velmi často používány při výzkumu procesu vyjednávání a tvorby koalic na úrovni Evropské rady (ER), kde otázka nalézání konsensu dominuje jednacímu procesu (Tallberg, 2008; Tallberg - Johansson, 2008). Stejně tak je možné v případě ER poukázat na ještě větší význam využívání neformálních kanálů pro vyjednávání (dlouhodobé osobní kontakty, schůzky či telefonické rozhovory mimo samotný rámec jednání apod.) než v př́padě Rady.
} 
dohodli“ (Rasch 1997, cit. podle Elgström - Bjurulf - Johansson - Sannerstedt 2001: 113). Klíčový je samotný proces koordinace jejich pozic, který nezř́dka předchází vlastnímu vyjednávání v Radě, př́ípadně jej doprovází též na neoficiální úrovni. Někteří autoři dokonce tuto fázi považují za klíčovou, a to jak z hlediska další interakce členských států, tak z hlediska vysvětlení jejich koaličního chování. Kvalitativní výzkum přistupující k tvorbě koalic jakožto k procesu se proto může zabývat i významem vyjednávání mezi reprezentanty členských států $\mathrm{v}$ přípravné fázi, které nakonec ústí ve vlastní vytvoření koalice, a z tohoto hlediska zkoumat, jaké faktory ovlivňují vyjednávací potenciál členských států, př́padně jaké jsou kauzální vztahy mezi průběhem pre-negociační fáze a typem koalic, které následně vznikají (Ruse 2010).

Prostř̌ednictvím kvalitativního výzkumu je tedy možné sledovat historii vyjednávacího procesu, jeho průběh v různých fázích, včetně oné neformální dimenze, jejíž velmi důležitá role je dalším prvkem, který by neměl ujít pozornosti výzkumníka, pokud chce porozumět procesům, které se na jednotlivých úrovních Rady odehrávaji1. ${ }^{17}$ Kvalitativní výzkum tak umožňuje identifikovat důležité faktory, které ovlivňovaly strategické úvahy aktérů (Aus 2008: 114) a které jsou pomocí kvantitativního výzkumu obtížně zachytitelné. Právě výzkum neformálních procesů a jejich významu přitom považují někteří autoři za stále ještě nedostatečný, ${ }^{18}$ i když poměrně obtížný nejen z metodologického hlediska (Nugent - Paterson 2010: 76). Do procesu utváření různých vyjednávacích strategií přitom vstupuje řada důležitých faktorů endogenní i exogenní povahy. $\mathrm{V}$ procesu koordinace je možné zabývat se již zmíněnými motivacemi aktérů (např. Hosli, 2001), které mohou být výsledkem nejen racionální volby, ale i zohlednění určitých norem, identit, ustálených vzorců chování, sociálního učení aktérů apod. Kvalitativní výzkum umožňuje postihnout některé zajímavé fenomény, které $\mathrm{v}$ praxi tradičně patř́ $\mathrm{k}$ tzv. komunitární metodě rozhodování, jako jsou balíková jednání, logrolling, „výměnné obchody“ v rámci př́slušné tematické formace Rady, ale i např́ic projednávanými tématy a jejich využívání v prrípadě státu, jehož koaliční chování je předmětem zkoumání (Zbíral 2008b: 104). I když je třeba podotknout, že těmito fenomény se snaží v poslední době zabývat také kvantitativní tradice. Tyto jevy mohou mít $\mathrm{z}$ hlediska motivace aktérů primárně racionální povahu, aktéři však opět nemusejí sledovat jen krátkodobý ad hoc zájem, ale př́slušné rozhodnutí může být i součástí utváření dlouhodobých

\footnotetext{
17 Novějším výzkumem soustředěným na reprezentanty v rámci pracovních skupin, který si všímá neformální dimenze spolupráce $\mathrm{v}$ Radě (procesu konzultací a výměny informací mezi zástupci členských států mimo oficiální schůzky pracovních skupin Rady), je výzkum Marta Laatsita a Michaela Keadinga z European Institute of Public Administration. Autoři se $\mathrm{v}$ něm prostřednictvím komparace 4 př́padových studií a za užití techniky polostrukturovaných rozhovorů se zástupci vybraných členských států v pracovních skupinách Rady pokusili odpovědět nejen na otázku, zda po východním rozšíření EU stále přetrvává na úrovni pracovních skupin Rady spolupráce „severních“ zemí na jedné straně a ,jižních“ států na straně druhé. Kvalitativní rozhovory jimiž autoři doplňovali výsledky dotazníkového šetření, jim následně umožnily také hlubší zkoumání motivů jednotlivých zástupců členských států pro kontaktování jejich protějšků i mimo oficiální zasedání pracovních skupin, stejně tak jako hlubší analýzu vybraných př́ípadů (Laatsit - Keading 2011).

${ }^{18}$ Lze přitom konstatovat, že v kontextu současného vývoje EU význam této dimenze stoupá. V posledních letech lze v souvislosti s řešením krize eurozóny a se snahami o prohlubování integrace v určitých oblastech souvisejících s finanční a ekonomickou dimenzí sledovat nárůst frekvence summitů a také nárůst důležitosti neformálních kanálů jednání, které probíhají paralelně s oficiální rovinou jednání nebo jí předcházejí. Snahy o prohlubování integrace v některých oblastech narážejí na nesouhlas členských států, lze proto pozorovat vznik skupin států snažících se stát vně některých aktivit, nebo naopak být jejích součástí (viz např. posílená spolupráce týkající se tzv. daně z finančních transakcî). To jsou opět fenomény posilující význam neformálních jednání a jednání probíhajících mimo oficiální hlavní komunikační kanály.
} 
záměrů, které formují na jedné straně „pravidla hry“ v rámci instituce a na druhé straně zpětně ovlivňují proces utváření a hájení zájmů z pozice jednotlivých aktérů-států. Kvalitativní výzkum také dovede zachytit rozdíly v chování aktérů-států, respektive jejich reprezentantů, v různých tematických oblastech či $\mathrm{v}$ případě důležitých dílčích témat $\mathrm{v}$ rámci určité širšś agendy (Heisenberg 2008: 272).

Od poznatku, že instituce formují a de facto vytvářejí (či lépe řečeno spoluvytvářejí, za aktivní součinnosti svých členů) určité normy a způsoby chování, ale i ideje, jejichž prostřrednictvím bývá toto chování následně obhajováno a legitimizováno (Lowndes 2010: 65), lze dospět k problematice utváření koaličních vzorců. I tato problematika může být zkoumána prostřednictvím kvalitativního výzkumu a jeho technik, vhodně doplňujících existující poznatky výzkumů kvantitativních. Zájmy, které aktéři v rámci př́slušné institucionální struktury hájí, jsou ovlivňovány kulturním kontextem a také kontextem předcházející, často dlouhodobé spolupráce, která vyplývá z určité ideové či jiné blízkosti. Pokud bychom se přidržovali konstruktivistických východisek, lze se $\mathrm{v}$ rámci př́slušného výzkumu věnovat např. otázce, $\mathrm{zda} \mathrm{v}$ př́ípadě př́slušného státu, jehož koaliční chování zkoumáme, působí vliv tohoto kontextu na zájmy a rozhodování aktérů jako významnější faktor nežli racionální úvaha, na jejímž základě by aktéři tyto zájmy přizpo̊sobovali momentální situaci ve snaze dosáhnout vždy především optimálního výsledku. $\mathrm{V}$ př́padě výzkumu utváření koalic na různých úrovních Rady tak napríklad z konstruktivistických východisek vycházejí předpoklady o existenci dlouhodobějších, stabilních koalic založených na sdílených normách, sdílené identitě, zájmech, které postupně konvergují na základě předchozí spolupráce apod. Institucionalismus racionální volby naproti tomu hovoří o vytváření efektivních ad hoc koalic stejně smýšlejících států v případě partikulární legislativy, jejichž prostřednictvím státy maximalizují svůj užitek $z$ výsledku jednání. ${ }^{19}$

Kvalitativní výzkumy operující s různými koaličními vzorci (typicky ad hoc koalice na jedné straně a institucionalizované koalice na straně druhé) se často zaměřují např. na určitou skupinu zemí, geograficky kompaktní, případně skupinu vykazující na jiné úrovni, než je úroveň EU, více či méně institucionalizovanou spolupráci (např. severské státy, př́ípadně státy Visegrádské skupiny). Zaměřují se potom např. na motivy, které vedly zástupce vlád těchto jednotlivých států k upřednostnění toho či onoho typu koaliční spolupráce v konkrétních př́padech (Ruse 2010, 2011), prípadně ke změnám těchto preferencí v průběhu vyjednávacího procesu. Výzkumy zaměřené na výskyt koaličních vzorců v Radě se mohou soustřed'ovat také na potvrzení existence či platnosti určitých konkrétních cleavages při tvorbě koalic, např. existence dělící linie nové členské státy vs. starší členové po východním rozšiřování EU (Lempp 2007).

V neposlední řadě je třeba vzít v úvahu také skutečnost, že Rada jakožto instituce neexistuje ve vakuu, ale je součástí institucionálního systému, v jehož rámci se vytvářejí vazby (opět nejen na oficiální úrovni) vyplývající z toho, jak je institucionální struktura definována v primárním právu. Kvalitativní výzkum umožňuje zaměřit se také $z$ tohoto hlediska na vyjednávací schopnosti aktérů a jejich vztahy k dalším institucím, které se podílejí na rozhodovacím procesu (např. Rada

19 Př́kladem kvalitativního výzkumu (s využitím př́padových studií a polostrukturovaných rozhovorů), jehož předmětem byla výhodnost či význam utváření těchto různých typů koalic, může být výzkum Ilze Ruse (2010). 
a Evropský parlament, viz Farrell - Héritier, 2004). Takovýto výzkum lze využít př́i zkoumání procesů, př́ nichž dochází k utváření sítí kontaktů (formálních i neformálních) napříč institucemi a ke zkoumání významu takových sítí např. při ovlivňování procesu utváření koalic v Radě. ${ }^{20}$

Pro př́pad zkoumání koaličního chování členského státu (případně skupiny států) tedy platí, že kvalitativní výzkum umožňuje získat sadu dat, která vhodně doplňují např. poznatky kvantitativního výzkumu týkajícího se koaličních vzorců, ale mohou se stát i bází pro další, kvantitativní výzkum. ${ }^{21}$ Kvalitativní výzkum umožňuje především více detailní zaměření např. na konkrétní aspekty koaličního chování (řešení otázky, jakou roli hraje při konkrétním procesu vyjednávání adaptace na tyto procesy jednak u stálých zástupců členských států, jednak u vyjednavačů vysílaných do pracovních skupin Rady jednotlivými resorty apod.), na roli neformálních procesů a dalších specifik vyjednávání, která se odehrávají mimo vlastní institucionální strukturu Rady (např. role a funkce bilaterálního vyjednávání mezi členskými státy), na různé dílčí kvalitativní změny v procesu hledání konsensu na úrovni Rady (např. pod vlivem východního rozšiřování $\mathrm{EU}$ ), na jejich zhodnocení apod. V př́ípadě výzkumu koaličního chování a působení př́slušných členských států v Radě jakožto aktérů vyjednávacího procesu, který je založen na kvalitativní výzkumné tradici, tedy platí to, co lze obecně konstatovat o tomto typu výzkumu: Umožňuje soustředit se na data a faktory, které následně pomáhají lépe porozumět tomuto chování i samotným procesům probíhajícím v Radě a vhodně je interpretovat s ohledem na reálné fungování těchto procesů (Vromen 2010: 250-255).

\footnotetext{
20 Nap̌r. prostřednictvím výzkumu založeného na technice elite interviewing provedené mezi zainteresovanými úředníky, diplomaty či politiky (poslanci EP apod.).

21 Data získaná na základě technik typických pro kvalitativní výzkum, jako jsou např. často využívané polostrukturované rozhovory (nap̌r. s reprezentanty členských států), mohou doplňovat „tvrdá“ data získaná na základě zápisů a tiskových zpráv z jednání Rady, statistik atd. zpracovávaných při výzkumu koaličních vzorců prostřednictvím různých technik, jež nabízí kvantitativní výzkum. Např. Van Aken kvantitativní výzkum prováděný na základě datového souboru výsledků veřejných a zaznamenaných hlasování v letech 1995 - 2010, zpracovávaných statistickými metodami (jako je shluková analýza), doplňuje kvalitativním výzkumem na základě rozhovorů s účastníky jednání Rady, zástupci Generálního sekretariátu Rady či stálých zastoupení členských států (Van Aken 2012). Př́kladem zkoumání, v němž se doplňují techniky kvantitativního a kvalitativního výzkumu může být i studie Elgströma, Bjurulfa, Johanssona a Sannerstedta z roku 2001. Studie kombinuje zkoumání pomocí standardizovaných dotazníků adresovaných přislušným úředníkům a zaměřených obecně na frekvenci výskytu určitých koaličních vzorců či na frekvenci spolupráce zástupců př́slušného státu se zástupci státu jiného s výzkumem prováděným prostřednictvím konkrétních case studies. Tyto př́padové studie jim umožňují odpovědět např. na otázku, jaké motivy stojí v pozadí koaličního chování členského státu (zda je volba pro spolupráci s určitými partnery ovlivňována společným zájmem v konkrétní oblasti, nebo ji ovlivňují také kulturní motivy apod.) (Elgström - Bjurulf - Johansson - Sannerstedt 2001).

Kvalitativní výzkum prostřednictvím case studies (opět za využití rozhovorů s příslušnými úředníky evropských institucí a zástupci členských států) je využíván $\mathrm{k}$ doplnění práce s kvantitativními daty (např. v podobě datasetů operujících s objemem přijaté legislativy, s počítáním negativních hlasů či abstencí, sledujících délku schvalovacího procesu, podíl legislativních aktů přijímaných s předchozí debatou či bez diskuse apod.) také v některých studiích zaměřených na změny nastávající v negociačním procesu Rady pod vlivem východního rozšiřování EU (Best Setembri 2007) apod.

Př́kladem jednoho z nejnovějších výzkumů, který se týká faktorů ovlivňujících vyjednávání v Radě a chování členských států (respektive jejich zástupců) v tomto procesu a který využívá jak techniky dotazníku, tak kvalitativních polostrukturovaných rozhovorů se zástupci členských států v Radě, může být např. výzkum Markuse Johanssona představený na 13th European Union Studies Association biennial conference v Baltimore v květnu 2013. Konkrétně se ve výzkumu opírajícím se z teoretického hlediska mimo jiné o Putnamovu teorii dvouúrovňové hry jedná o vztah mezi problémy na úrovni domácí politiky a schopností zástupců členského státu využívat svoji vyjednávací sílu na mezinárodní úrovni ( $v$ tomto př́padě na úrovni Rady EU), přičemž stojí za zmínku, že zástupci ČR (spolu s reprezentanty Rumunska a Litvy) mezi respondenty chyběli (Johansson 2013).
} 


\section{Závěr}

Předcházející text není a neměl být výzkumným článkem či studií stricto sensu. Jeho cílem jakožto úvodu do konkrétního výzkumu ČR coby aktéra v procesu vyjednávání a tvorby koalic v Radě bylo představení dvou alternativních přístupů k výzkumu Rady EU v kontextu specifik, jež Radu EU a koaliční chování v ní charakterizují. Je třeba zdůraznit, že poznatky kvalitativního a kvantitativního výzkumu se mohou při zkoumání procesu tvorby koalic, koaličního chování států či chování států v rámci procesu vyjednávání v Radě vhodně doplňovat, jak se v současnosti často děje (viz předchozí kapitola). Kvantitativní výzkum zaměřený na výsledky hlasování v Radě může přinést alespoň indikativní (vzhledem $\mathrm{k}$ již zmíněnému malému procentu prípadů, $\mathrm{v}$ nichž dochází ke skutečnému hlasovánî) informaci o existenci př́slušných cleavages mezi členskými státy (například noví versus starší členové, zastánci protekcionismu v obchodních vztazích versus stoupenci liberalizace, čistí plátci versus čistí prŕjemci). O tyto předpoklady je následně možné opřít výzkum kvalitativní, zaměřený (prostřednictvím rozhovorů s reprezentanty členského státu/států) na možnost existence trvalejších koalic v prř́slušné oblasti i na samotný proces proměny pozic při jednání na různých úrovních Rady a motivy těchto proměn (Lempp 2007: 36).

Zadání našeho výzkumu se týká samotného procesu prosazování zájmů ČR v Radě EU s důrazem na budování koalic a hledání kompromisů, tedy i na jednání zástupců ČR v procesu vyjednávání na různých úrovních Rady. Z výše uvedených charakteristik možností, které nabízejí jednak kvantitativní, jednak kvalitativní výzkum, tedy vyplývá, že jsme pro náš konkrétní případ zvolili především nástroje výzkumu kvalitativního, konkrétně techniku elite interviewing.

Tato technika byla zvolena s ohledem na požadované cíle a účely př́slušného výzkumu (zaměření nikoli na exaktní výsledky jednotlivých hlasování, ale na samotnou praxi vyjednávání při vytváření koalic s konkrétními partnery ve zkoumaných oblastech a na faktory, které toto koaliční chování a působení ČR jako aktéra v Radě EU ovlivňujî). Jak již vyplývá z předchozího přehledu prŕikladů výsledků a možností kvalitativního výzkumu, rozhovory jsou častou výzkumnou technikou v př́padě, chce-li výzkumník zachytit osobní reflexi událostí ze strany přímých účastníků procesu vyjednávání. Výzkum prováděný touto technikou byl v minulosti využíván např. k detailnímu zkoumání procesu vyjednávání na určitých úrovních Rady (např̀. pouze $\mathrm{v}$ pracovních skupinách) či k detailnímu zkoumání samotného procesu a různých technik vyjednávání v praxi (např. způsobů dosahování kompromisu, využívání neformálních technik vyjednávání a tvorby koalic). Je jí využíváno také ke zkoumání specifických faktorů ovlivňujících vyjednávání a dosahování kompromisu (např. jak se tyto způsoby liší u úředníků ukotvených ve strukturách stálého zastoupení v Bruselu, či naopak u úředníků vysílaných př́slušným státem, jak se liší využívání neformálních procesů kooperace a tvorby koalic u zástupců novějších a starších členských států, s ohledem na proces socializace apod.). V minulosti byl tento výzkum použit i za účelem zjištění, zda po východním rozšíření nadále na př́slušných úrovních Rady přetrvává skupinová spolupráce např. zemí „Jihu“ na jedné straně a zemí „Severu“ na druhé straně, př́padně jaké jiné motivy $\mathrm{v}$ př́islušných oblastech motivují zástupce členského státu ke koaliční spolupráci. Technika kvalitativních rozhovorů byla tedy použita i v prŕípadě výzkumů zabývajících 
se výhodností či významem utváření různých typů koalic pro př́islušný členský stát či skupinu států. Ukázala se ale jako vhodný nástroj např. i při zkoumání vztahu mezi problémy na úrovni domácí politiky a schopností zástupců př́islušných členských států využívat svoji vyjednávací sílu na úrovni EU.

Obecné poznatky kvantitativní tradice, postulující existenci různých konfliktních linií v Radě EU, at' už se jedná o dominantní severo-jižní linii (potenciálně obohacenou o východní dimenzi) ${ }^{22}$ či další třecí plochy, jejichž výskyt jsme nastínili v kapitole věnované kvantitativní výzkumné tradici, stejně jako již zjištěné poznatky výzkumů kvalitativních, na které jsme upozornili v další části textu, mohou sloužit jako vhodné východisko ke kvalitativnímu výzkumu zaměřenému na Českou republiku jako aktéra v Radě EU. Cílem našeho výzkumu je v prvé řadě v př́padě ČR a analýzy jejího koaličního jednání detailně a do hloubky prozkoumat fungování obecných poznatků kvantitativní tradice v praxi. Domníváme se, že prostřednictvím polostrukturovaných rozhovorư $^{23} \mathrm{~s}$ přímými účastníky jednání na různých úrovních Rady, $\mathrm{v}$ prrípadě našeho výzkumu především na úrovni pracovních skupin a COREPERu a též dalších výborů ( $v$ praxi se tedy jedná především o rozhovory s reprezentanty jednotlivých ministerstev zastupujících své resorty na pracovních skupinách Rady, pracovníky Stálého zastoupení v Bruselu, zástupci členského státu ve strukturách COREPERu či členy Mertensovy a Anticiho skupiny) lze tyto obecné poznatky - v českém př́padě - prohloubit, nebo též určit jejich limity. ${ }^{24}$

Zpracováním dat získaných od stejných respondentů míníme zjistit, co vlastně konstruuje a ovlivňuje koaliční chování ČR. V této rovině existuje několik relevantních předpokladů. Již zmíněná teorie racionální volby, kterou využívá také liberální intergovernmentalismus, nabízí předpoklad o vytváření ad hoc koalic na základě konkrétních zájmových preferencí v jednotlivých oblastech. Velkou roli zde prritom hrají zájmy ekonomické. Z konstruktivistických premis naopak vychází předpoklad o existenci institucionalizovaných stálých koalic založených na geografické či kulturně-politické blízkosti či tradici skupinové politické spolupráce, jež vedou k tomu, že členové těchto skupin tendují v rámci jednání na různých úrovních Rady EU a na úrovni ER ke koaliční spolupráci navzdory z krátkodobého hlediska odlišným zájmům v různých tematických

\footnotetext{
${ }^{22} \mathrm{~V}$ první fázi výzkumu je východiskem ke sběru dat identifikace jednotlivých issue areas $\mathrm{v}$ rámci jednotlivých tematických formací Rady. Na jejich základě jsou průběžně identifikována klíčová politická témata, jež byla v období květen 2004 až prosinec 2012 předmětem vyjednání na různých úrovních Rady. Základním zdrojem dat pro tuto první fázi výzkumu jsou především tiskové zprávy Rady, informační databáze, z nichž je možné získat informace o výsledcích hlasování, složení winning coalitions, př́ípadně blokačních menšin při hlasování Rady prostřednictvím QMV. Sekundárním zdrojem informací je monitoring tisku a především informačních zdrojů věnujících se dění v EU a jejích institucích v souvislosti s projednáváním jednotlivých důležitých návrhů a témat.

${ }_{23}$ Technika elite interviewing, která je $\mathrm{k}$ získání těchto dat využita, má podobu vedení nestandardizovaných kvalitativních rozhovorů, nejčastěji ve formě polostrukturovaných rozhovorů s respondenty z řad zástupců „elit“".

${ }^{24}$ Zvolená technika může přinést odpovědi na otázku: Jak se projevuji obecné prédpoklady týkajicí se koaličnich vąorci v Radě $v$ jednotlivých tematických oblastech (issue areas) a na jednotlivých úrovních Rady? (s ohledem na specializaci a na profesní zkušenost respondenta). Jejím prostřednictvím je však možné ptát se i na otázky: Proč byla v partikulárním př́padě zvolena ta která koalični strategie? Zda docházelo v prüběbu procesu vyjednáváni ke zmènám? Cím byly tyto żmèny podminény? Jak proces artikulace a prosazováni zájmi členskébo státu v rámci struktury Rady ovlivnily takové faktory, jako je predsednictví v Radè? Jak respondenti hodnotí roli koordinace, spolupráce a podpory na národni úrovni? apod. Elite interviewing je cenný v tom, že dokáže zachytit individuální percepci či hodnocení respondenta ve vztahu k určitým jevům, úskalím potom může být výpověd’ zatížená faktory subjektivní zkušenosti a subjektivního hodnocení.
} 
oblastech. V úvahu je brán také předpoklad vytváření ad hoc koalic na základě ideové blízkosti vlád jednotlivých členských států. ${ }^{25}$

$\mathrm{V}$ druhé řadě, poznatky učiněné $\mathrm{v}$ př́padech výše zmíněných kvalitativních výzkumů je možné využít jako východiska pro zkoumání motivace ČR jakožto členského státu při utváření určitých typů koalic, jejich výhodnosti a významu v prŕśsušných tematických oblastech, které jim př́suzují respondenti s dlouhodobou zkušeností při vyjednávání na jednotlivých úrovních Rady. Lze je využít jako východiska pro výzkum chování ČR jako aktéra v samotném procesu vyjednávání (prověřování schopnosti konzistentního prosazování určité pozice, využívání neformálních nástrojů při tvorbě koalic, bilaterální spolupráce, logrollingu atd.) a také faktorů, které jej ovlivňují (koordinace na národní úrovni, střídání vlád, role CZ PRES, případně další faktory endogenní i exogenní povahy). Nosným tématem je z hlediska zkoumání role ČR jako aktéra $\mathrm{v}$ Radě EU za využití této techniky i výzkum spolupráce zástupců ČR v Radě s dalšími institucemi (především EK a EP) a jejich reprezentanty. ${ }^{26}$ Také v této rovině lze vysledovat relevantní teoretické základy. V př́padě institucionalismu racionální volby lze sledovat, zda členská země považuje instituce EU za nástroj prosazování svých zájmů, v případě přijetí konstruktivistické explanace jako východiska (př́padně akceptace východisek sociologického institucionalismu) je $\mathrm{v}$ této rovině zajímavé zkoumat, zda zmíněné instituce fungují jako aktér proměňující chování členského státu.

$\mathrm{K}$ přednostem zvolené výzkumné techniky náleží to, že umožňuje zachytit některá data v rámci výzkumu kvantitativními metodami a technikami jen obtížně zjistitelná. Prostřednictvím otevřených otázek, které jsou $\mathrm{v}$ průběhu rozhovoru vhodně doplňovány otázkami dílčími, umožňuje tato technika zkoumat vyjednávání nikoli ve statické podobě, ale jako dynamický proces, který je spoluutvářen jednotlivými aktéry, jež se ho účastní, a zároveň jednání těchto aktérů jsou utvářena tímto procesem. Tento typ výzkumné techniky taktéž dovede zprostředkovat percepci zkoumaných jevů ze strany respondentů, porozumět jejich postojům, myšlenkám a dojmům, které spoluutvářely také jejich chování (Burnham - Gilland Lutz - Grant - Layton-Henry 2008: 233, Dexter 2006: 31-65). Další, již zmíněnou výhodou je možnost zachycení neformálních procesů a jejich role ve vyjednávání. Výzkumník se tak může dostat $\mathrm{k}$ informacím, které by jinak nežli rozhovorem s přímým účastníkem zkoumaných procesů nezískal, což je obzvláště důležité, je-li motivací výzkumu snaha získat detailní informace o chování aktéra v Radě EU a různých motivech, které jej ovlivňují. Výzkum prostřednictvím elite interview má ale pochopitelně také své limity. Náleží k nim subjektivita respondenta či možnost zkreslené výpovědi. Negativní faktory subjektivity se ovšem týkají i tazatele, a to hned ve dvojím ohledu: první riziko se týká ovlivnění rozhovoru (např. výběrem otázek), tazatel by se proto měl vyhýbat napr. podsouvání určité odpovědi prostřednictvím sugestivních otázek apod. a

25 „Ideovou blízkosti“ se v tomto případě míní blízkost založená na cleavages levice/pravice, prointegrační/euroskeptický přístup příslušných politických stran, z nichž je složena vládní koalice, apod.

${ }^{26}$ Výzkum prostřednictvím elite interviews může v takovém prúpadě odpovídat napr. na otázky: Jak reprezentanti členskébo státu na jednotlivých úrovnich Rady hodnoti ve sledovaném obdobi v jednotlivých tematických oblastech spolupráci s EK a EP? (Př́klady úspěšné/efektivní spolupráce, a naopak př́klady vycházející z opačné zkušenosti.) Je z.jejich pobledu duiležité udry̌ování vazeb s pracovniky jiných instituci českého piovodu (komisař, eventuálnè jeho kabinet, zástupci v jednotlivých DG, čeśti zástupci v EP)? Jakým zpuisobem jsou tyto vazby udry̌ovány? Apod. 
poskytnout prostor respondentovi (Pierce 2008: 123-125). Druhé riziko se týká interpretace odpovědí (např. spekulativní interpretace či interpretace, do které tazatel promítá svá očekávání, hodnocení reality apod.). Souvisejícím problémem může být objektivita zpracování dat získaných na základě rozhovorů - překonat jej $\mathrm{v}$ některých př́padech může např. využití analytického softwaru sloužícího ke zpracování kvalitativních dat.

Jak jsme již uvedli v úvodu, výzkum chování státu v rámci procesů vyjednávání a tvorby koalic v Radě EU je komplexní a složité téma (již jen pro počet formací Rady a s ním související počet issues, jež jsou předmětem koaličního vyjednávání). Předkládaná konzultace proto měla sloužit nejen $\mathrm{k}$ představení našich východisek a vysvětlení zvoleného metodologického postupu, ale také jako inspirace dalším badatelům, které fungování Rady EU a partikulárně působení ČR jako aktéra v této instituci výzkumně zajímá.

\section{Literatura}

Alexandrova, P. - Timmermans, A. (2013): National interest versus the common good: The Presidency in European Council agenda setting. European Journal of Political Science, Vol. 52, No. 3, p. 316-338. DOI: 10.1111/j.1475-6765.2012.02074.x

Aspinwall, M. (2006): Government Preferences on European Integration: An Empirical Test of Five Theories. British Journal of Political Science, Vol. 37, p. 89-114.

Aus, J., P. (2008): The Machanisms of Consensus: Comming to Agreement on Community Asylum Policy. In: Naurin, D. - Wallace, H. (ed.): Unveiling the Council of the European Union. Games Government Play in Brussels. Houndmills: Palgrave Macmillan, p. 99-118.

Barr, J. - Passarelli, F. (2009): Who has the power in the EU? Mathematical Social Science, Vol. 57, No. 3, p. 339-366. DOI: 10.1016/j.mathsocsci.2008.12.007

Belko, M. (2009): Charakter medzištátného vyjednávania na pôde Rady Európskej únie. Mežinárodní vætahy, Vol. 44, No. 1, p. 86-107.

Best, E. - Settembri, P. (2007): Surviving enlargement: How has the Council managed? Paper presented to the EUSA Tenth Biennal International Conference, Montreal, 17 - 19 May 2007.

Beyers, J. (2005): Multiple Embeddedness and Socialization in Europe: The Case of Council Officials. International Organization, Vol. 59, No. 4, p. 899-936. DOI: 10.1017/S0020818305050319

Bostock, D. (2002): Coreper Revisited. Journal of Common Market Studies, Vol. 40, No. 2, p. 215-234. DOI: 10.1111/1468-5965.00352

Burnham, P. - Gilland Lutz, K. - Grant, W. - Layton-Henry, Z. (2008): Research Methods in Politics. Houndmills: Palgrave Macmillan.

Checkel, J., T. (2005): International Institutions and Socialization in Europe: Introduction andFramework. International Organization, Vol. 59, Iss. 04, October 2005, pp 801 - 826. DOI: $10.1017 /$ S0020818305050289

Chryssochoou, D. (2009): Theorizing European Integration. 2nd ed. London: Routledge. de Maillard, J. - Smith, A. (2003): Council Committees in the Government of the EU: Case-study Comparisons from the 1 st and 3rd Pillars. Paper presented at the congress of the European Union Studies Association, Nashville, Tennessee, March 27 - 29, 2003. 
de Maillard, J. - Smith, A. (2011): Understanding the EU's Council of Ministers through its committees: Existing knowledge and new directions for research. Cabiers de SPIRIT, SPIRIT Working Papers. Janvier 2011.

Decision-Making in the European Union Before and After Lisbon (DEUBAL). On-line: (http://www.ces.ufl.edu/DEUBAL/)

Dexter, L. A. (2006): Elite and specialized interviewing. Essex: ECPR.

Drulák, P. (2008): Epistemologie, ontologie a operacionalizace. In: Drulák, P. a kol.: Jak ₹łooumat politiku. Kvalitativni metodologie v politologii a mezinárodnich vætazích. Praha: Portál, s. 14 - 28.

Elgström, Ole - Bjurulf, Bo - Johansson, Jonas - Sannerstedt, Anders (2001): Coalitions in European Union Negotiations. Scandinavian Political Studies, Vol. 24 , No. 2, p. 111-128. DOI: 10.1111/14679477.00049

Farrell, Henry - Héritier, Adrienne (2004): Inter-organizational Negotiation and Intra-organizational Power in Shared Decision-making. Early agreements under codecision and their impact on the European Parliament and the Council of Ministers. Political Science Series. Institut für Höhere Studien (IHS), Wien.

Fiala, P. - Pitrová, M. (2009): Europská unie. Brno: Centrum pro studium demokracie a kultury.

Fouilleux E. - de Maillard, J. - Smith, A. (2005). Technical or political? The working groups of the EU Council of Ministers. Journal of European Public Policy, Vol. 12, No. 4, p. 609-623. DOI: 10.1080/13501760500160102

Häge, F. M. (2008): Who Decides in the Council of the European Union? Journal of Common Market Studies, Vol. 46, No. 3, p. 533-558. DOI: 10.1111/j.1468-5965.2008.00790.x

Häge, Frank M. (2007): Committee Decision-making in the Council of the European Union. European Union Politics, Vol. 8, No. 3, p. 299-328. DOI: 10.1177/1465116507079539

Hagemann, S. - Høyland, B. (2008): Parties in the Council? Journal of European Public Policy, Vol. 15, No. 8, p. 1205-1221. DOI: 10.1080/13501760802407714

Hagemann, S. (2008): Voting, Statement and Coalition Budilding in the Council form 1999 to 2006. In: Naurin, D. - Wallace, H. (ed.): Unveiling the Council of the European Union. Games Government Play in Brussels. Houndmills: Palgrave Macmillan, p. 36-63.

Hayes-Renshaw, F. - Van Aken, W. - Wallace, H. (2006): When and Why the EU Council of Ministers Votes Explicitly', Journal of Common Market Studies, Vol. 44, No. 1, p. 161-94.

Hayes-Renshaw, F. - Wallace, H. (2006): The Council of Ministers. Basingstoke: Palgrave Macmillan.

Heisenberg, D. (2005): The institution of 'consensus' in the European Union: Formal versus informal decision-making in the Council. European Journal of Political Research, Vol. 44, No. 1, p. 65-90. DOI: 10.1111/j.1475-6765.2005.00219.x

Heisenberg, D. (2008): How Should We Best Study the Council of Ministers? In: Naurin, Daniel Wallace, Helen (ed.): Unveiling the Council of the European Union. Games Government Play in Brussels. Houndmills: Palgrave Macmillan, p. 261-276.

Hosli, M. - Machover, M. (2004): The Nice Treaty and Voting Rules in the Council: A Reply to Moberg (2002). Journal of Common Market Studies, Vol. 42, No. 3, p. 497-521. DOI: 10.1111/j.00219886.2004.00516.x

Hosli, M. - Mattila, M. - Uriot, M. (2011): Voting in the Council of the European Union after the 2004 Enlargement: A Comparison of Old and New Member States. Journal of Common Market Studies, Vol. 49, No. 6, p. 1249-1270. DOI: 10.1111/j.1468-5965.2011.02196.x 
Hosli, M. (1999): Power, Connected Coalitions and Efficiency: Challenges to the Council of the European Union. International Political Science Review, Vol. 20, No. 4, p. 371-391. DOI: 10.1177/0192512199204004

Johansson, M. (2013): Domestic Constraints Tactics in the Council of the EU. Paper prepared for the 13th European Union Studies Association biennial conference, Baltimore May 9-11 2013.

Juncos, A., E. - Pomorska, K. (2007): The Deadlock that never Happened:the Impact of Enlargement on theCommon Foreign and Security Policy Council Working Groups. European Political Economy Review. No. 6 (March 2007), p. 4-30.

Kaniok, P. (2008): Predsednictví Rady EU - př́bẻh prilstoletí. Brno: Mezinárodní politologický ústav.

Konsolidované znění Smlouvy o Evropské unii a Smlouvy o fungování Evropské unie (Úřední věstník Evropské unie C 115/2008).

Kořan, M. (2008): Jednoprrípadová studie. In: Drulák, P. a kol.: Jak zkoumat politiku. Kvalitativní metodologie v politologii a mezinárodnich væ̨tazićch. Praha: Portál, s. 29 - 61.

Laatsit, M. - Kaeding, M. (2011): It's the Centre-Periphery, Stupid! Cooperation Patterns in the Council of Ministers after Enlargement. European Institute of Public Administration, working paper 2011/W/02.

Lempp, J.(2007): "Coreper Enlarged": how Enlargement Affected the Functioning of the Committee of Permanent Representatives. European Political Economy Review. No. 6 (March 2007), p. 31-52

Lewis, J. (2003): Institutional Environments And Everyday EU Decision Making. Rationalist or Constructivist? Comparative Political Studies. Vol. 36, No. 1-2, p. 97-124

Lowndes, V. (2010): The Institutional Approach. In: Marsh, D. - Stoker, G. (ed.): Theory and Methods in Political Science. 3rd ed. Houndmills: Palgrave Macmillan, p. 60 - 79.

Mattila, M. - Lane, J.-E. (2001): Why Unanimity in the Council? A Roll Call Analysis of Council Voting. European Union Politics, Vol. 2, No 1, p. 31-52. DOI: 10.1177/1465116501002001002

Mattila, M. (2004): Contested Decisions - Empirical Analysis of Voting in the EU Council of Ministers. European Journal of Political Research, Vol. 43, No. 1, p. 29-50. DOI: 10.1111/j.1475-6765.2004.00144.x

Mattila, M. (2009): Voting in the Council of the European Union after the 2004 Enlargement: A Comparison of Old and New Member States. European Journal of Political Research, Vol. 48, No. 6, p. 840-857. DOI: 10.1111/j.1475-6765.2009.01850.x

Naurin, D. - Lindahl, R. (2008): East-North-South: Coalition-Building in the Council before and after Enlargement. In: Naurin, D. - Wallace, H. (ed.): Unveiling the Council of the European Union. Games Government Play in Brussels. Houndmills: Palgrave Macmillan, p. 64-80.

Naurin, D. - Wallace, H. (2008): Introduction: from Rags to Riches. In: Naurin, Daniel - Wallace, Helen (ed.): Unveiling the Council of the European Union. Games Government Play in Brussels. Houndmills: Palgrave Macmillan, p. $1-20$.

Naurin, D. (2007): Network Capital and Cooperation Patterns in the Working Groups of the Council of the EU. EUI Working Papers RSCAS 2007/14.

Nugent, N. - Paterson, W. (2010): The Europen Union's Institutions. In: Egan, Michelle - Nugent, Neill - Paterson, W. (ed.): Research Agendas in EU Studies. Stalking the Elephant. Houndmills: Palgrave Macmillan, p. 60-91.

Olsen, I. (2010): The Council Working Groups - Advisors or de facto Decision Makers? Conference paper for the Fifth Pan-European Conference on EU Politics, Porto, Portugal, 23-26 June 2010

Parízek, M. (2012): After the Enlargement: Trends and Threats in the European Union Decision-Making. Perspectives. Review of International Affairs, Vol. 20, No. 1, p. 33-57.

Pierce, Roger (2008): Research Methods in Politics, a practical guide. London: SAGE. 
Plechanovová, B. (2004): Institucionální vývoj Evropské unie. Od Maastrichtské smlowy ke východnímu rožšrirení. Praha: Karolinum.

Plechanovová, B. (2006): Je rozhodovací procedura v Radě spravedlivá? Principy zastoupení a důsledky změn rozhodovací procedury navrhované ústavní smlouvou. Mezinárodní vztahy, Vol. 41, No. 1, p. $5-22$.

Plechanovová, B. (2011a): The EU Council enlarged: North-South-East or core-periphery? European Union Politics, Vol. 12, No. 1, p. 87-106. DOI: 10.1177/1465116510390720

Plechanovová, B. (2011b): Coalitions in the EU Council: Pitfalls of Multidimensional Analysis. AUCO Crech Economic Review, Vol. 5, No. 3, p. 249-266.

Pollack, M. A. (2002): International Relations Theory and European Integration. Journal of Common Market Studies, Vol. 39, No. 2, p. 221-244. DOI: 10.1111/1468-5965.00286

Risse, T. (2009): Social Constructivism and the European Union. In: Wiener, A. - Diez, T. (ed.): European Integration Theory. 2nd ed. Oxford: Oxford University Press, p. 144-160.

Ruse, I. (2010): Factors Producing Coalitions in the EU Council Negotiations with Different Heterogeneity of the Member States' Policy Preferences. Conference paper for SGIR conference 2010, Stockholm, September $8-10$.

Ruse, I. (2011): Bargaining Power of Nordic-Baltic coalition in EU Council Negotiations. Paper presented at the ECPR Conference, Reykjavik 24-27 August, 2011.

Schalk, J. - Torenvlied, R. - Weesie, J. - Stokman, F. (2007): The Power of the Presidency in EU Council Decision-making. European Union Politics, Vol. 8, No. 2, p. 229-250.

Schneider, G. (2008): Neither Goethe nor Bismarck: on the Link between Theory and Empirics in Council Decision-Making Studies. In: Naurin, Daniel - Wallace, Helen (ed.): Unveiling the Council of the European Union. Games Government Play in Brussels. Houndmills: Palgrave Macmillan, p. 277 - 289.

Taagepera, R. - Hosli, M. (2006): National Representation in International Organizations: The Seat Allocation Model Implicit in the European Union Council and Parliament. Political Studies Vol. 54, No. 2, p. 370-398. DOI: 10.1111/j.1467-9248.2006.00607.x

Tallberg, J. - Johansson, K. M. (2008): Party politics in the European Council. Journal of European Public Policy. Vol. 15, No. 8, p. 1222-1242. DOI: 10.1080/13501760802407755

Tallberg, J. (2008): Bargaining Power in the European Council. Journal of Common Market Studies. Vol. 46, No. 3, p. 685-708. DOI: 10.1111/j.1468-5965.2008.00798.x

Thomson, R. - Boerefijn, J. - Stokman, F. N. (2004): Actor Alignments in European Union Decision Making. European Journal of Political Research, Vol. 43, No. 2, s. 237-261. DOI: 10.1111/j.14756765.2004.00153.x

Thomson, R. (2006): The European Union decides. Cambridge: Cambridge University Press.

Van Aken, W. (2012): Voting in the Council of the European Union. Contested Decision-Making in the EU Council of Ministers (1995-2010). Stockholm: Swedish Institute for European Policy Studies.

Veen, T. (2011): The dimensionality and nature of conflict in European Union politics: On the characteristics of intergovernmental decision-making. European Union Politics, Vol. 12, No. 1, p. 65-86. DOI: $10.1177 / 1465116510391918$

Vromen, A. (2010): Debating Methods: Rediscovering Qualitative Approaches. In: Marsh, D. - Stoker, G. (ed.): Theory and Methods in Political Science. 3rd ed. Houndmills: Palgrave Macmillan, p. 249 - 266.

Warntjen, A. (2007): Steering the Union. The Impact of the EU Presidency on Legislative Activity in the Council. Journal of Common Market Studies, Vol. 45, No. 5, p. 1135-1157. DOI: 10.1111/j.14685965.2007.00763.x 
Zbíral, R. (2008a): Zdroje moci členských států v Radě Evropské unie. Současný stav výzkumu. Mezinárodní vżtaby, Vol. 43, No. 4, p. 32-53.

Zbíral, R. (2008b): Teorie a praxe vyjednávání v Radě Evropské unie. Brno: muni press.

\section{Examining Coalitions in the Council of the European Union. Analysis of Research Approaches to Coalition Behavior in the Council}

\section{SUMMARY}

In recent years, also in the Czech Republic, there has been a growth in the number of research studies devoted to the behavior of member states in the EU Council. In contrast, the coalition-oriented behavior of the Czech Republic in this key EU institution has not been systematically studied. Now, after ten years of Czech EU membership and the activities of Czech representatives at all levels of the EU Council, there are enough data, not only of a quantitative, but also qualitative nature, to enable us to attempt to answer the following questions: "What is the position of the Czech Republic in the EU Council? What kind of actor is the $\mathrm{CR}$ in the processes of negotiation and coalition building in the framework of this intergovernmental institution?"

This paper represents an introduction to particular research into the coalition behavior of the CR, and aims to examine how, in the case of this particular member state (which is still a relatively young EU member), general assumptions concerning coalition formulas work in particular thematic areas and at particular levels of the EU Council. On the one hand, the research is based on the theoretical approach of rationalism and rational choice theory, which operates with the assumption of the existence of ad hoc coalition-building based on particular interest preferences. On the other hand, it also takes into consideration the premises of constructivism (which, to a considerable extent, has also influenced research into institutions and the theoretical approach of new institutionalism). This approach emphasizes the importance of certain institutionalized, stable coalitions based on geographical or cultural-political proximity and the tradition of group cooperation in the political dimension etc. (In the case of member states which entered the EU in 2004, this is typically cooperation on the basis of the Visegrád group.) In the research itself we try not only to examine which types of coalitions are preferred by a particular state and under which conditions, but also to identify the motives which cause the representatives of the CR to choose particular coalition partners and to change their coalition behavior etc., as well as to identify other factors (both of an endogenous and exogenous nature) that enter into the process of negotiations. To achieve this, we first have to examine the advantages and disadvantages of both quantitatively and qualitatively oriented research of coalitions in the EU Council and of the coalition behavior of member states (or a single state). On the basis of reflecting on both these research traditions (considering specific characteristics of the EU Council as an institution), we try to determine the questions that may be answered better by the respective approaches to research on the topic of coalitions.

In the first part, we briefly introduce the EU Council, its basic functions and characteristics, emphasizing the specificities of its role in the EU political system. This is because the subject of our research - the coalition behavior of a member state as an actor in the negotiation process - is inseparable from the issue of the Council as an institution, which works in a special manner and within which the activities of an actor are guided by special rules. Therefore, it is necessary to ask whether both the specific nature connected with the structure, norms and processes typical of the Council as well as the behaviour 
of actors representing member states do not have particular implications also for the choice of a particular methodology. The second part of the text focuses on an analysis of the current state of quantitative research explaining the behavior of member states in the EU Council, while the third part presents the qualitative tradition and its explanatory potential. The final part then summarizes our conclusions concerning current research into the coalition behavior of particular member states and outlines the direction of our further research.

The present paper serves not only to present the starting points of our research and to explain our methodological approach, but also as a springboard for future researchers who are interested in the workings of the EU Council and particularly the activities of the CR as an actor in this institution. It illustrates the fact that the forms of knowledge which both quantitative and qualitative research bring in the exploration of the process of coalition building and the behavior of member states in the processes of negotiation can supplement each other. Quantitative research focused on the results of voting in the Council may bring at least indicative information (considering the relatively small number of cases when real voting occurs) about the existence of particular cleavages between member states (e.g. the cleavage new vs. old members, trade protectionists vs. liberals, net payers vs. net recipients etc.). Qualitative research could then employ these findings, focusing on the existence of more stable coalitions in particular areas and on the actual process of changing position (and on the possible reasons for such changes) during negotiations at different levels of the EU Council. Qualitative interviews with representatives of member states (elite interviews) are a suitable research tool for this kind of research, considering the fact that our research was focused on the actual process of the promotion of the interests of the CR in the Council with an emphasis on coalition building and searching for compromises.

Using semi-structured qualitative interviews with direct participants of negotiations at different levels of the Council (in the case of our research, especially at the levels of working groups, COREPER, and other committees, i.e. with representatives of departments of member states' governments, employees of the Permanent Representation in Brussels, representatives of member states in COREPER, members of the Mertens group etc.), we can deeply explore the general assumptions outlined above in the case of the Czech Republic, interpret them, and possibly detect their limits in this particular case. The findings acquired on the basis of this qualitative research can be used as a starting point for further research into the motivations of the $\mathrm{CR}$ as a member state in building certain types of coalitions (i.e. research based on the importance and advantages assigned to these coalition formulae by respondents with longer experience of negotiations at particular levels of the Council). They can also be further used as a basis for research into the $\mathrm{CR}$ as an actor in the negotiation process (the exploration of its ability to promote certain positions in a consistent way and to use effectively different kinds of instruments in building coalitions, including informal instruments, bilateral cooperation, logrolling etc.) and into important factors influencing the Czech Republic's activities in these processes (coordination at the national level, changes of government, the role of experience with the EU Council Presidency etc.). 